\title{
Antimicrobial Resistance Properties of Staphylococcus Aureus Isolates From Powdered Packaged Medicinal Plants and Bottle Herbal Distillates
}

Zohreh Mashak

Karaj Islamic Azad University

Bahareh Tavakoli-Far ( $\sim$ bahtavakolifar@yahoo.com )

Alborz University of Medical Sciences

\section{Research}

Keywords: Staphylococcus aureus, Phenotypic resistance, Genotypic resistance, Medicinal plants, Herbal Distillates

Posted Date: December 2nd, 2020

DOI: https://doi.org/10.21203/rs.3.rs-116659/v1

License: () (7) This work is licensed under a Creative Commons Attribution 4.0 International License. Read Full License 


\section{Abstract}

Background

Human involvement in the production and processing of medicinal plants and herbal distillates caused a potential risk of microbial contamination, particularly with Staphylococcus aureus. The present research was performed to assess the prevalence and phenotypic and genotypic properties of antibiotic resistance of $S$. aureus bacteria isolated from diverse kinds of powdered packaged medicinal plant and bottle herbal distillate samples.

Methods

Three-hundred different powdered packaged medicinal plant and bottle herbal distillate samples produced in traditional conditions were collected and examined by the culture method. Phenotypic and genotypic patterns of antibiotic resistance of $S$. aureus isolates were examined using disk diffusion and PCR techniques.

Results

Thirty out of three-hundred (10\%) powdered packaged medicinal plant and bottle herbal distillate samples were contaminated with $S$. aureus. The prevalence of $S$. aureus amongst the powdered packaged medicinal plant and bottle herbal distillate samples were $8.33 \%$ and $11.11 \%$, respectively. A. citrodora (10\%) and R. damascene (10\%) powdered packed medicinal plants and A. maurorum (16.66\%) bottle herbal distillate had the highest contamination rate with $S$. aureus. S. aureus isolates harbored the highest prevalence of resistance toward penicillin (93.33\%), tetracycline (90\%), gentamicin (86.66\%), erythromycin (70\%), trimethoprim-sulfamethoxazole (63.33\%) and ciprofloxacin (53.33\%). Totally, $13.33 \%$ of the $S$. aureus isolates harbored resistance toward more than 7 antibiotic agents. blaZ (63.33\%), tetK (60\%), ermA (46.66\%), $m s r A(43.33 \%)$, aacA-D (43.33\%), and $\operatorname{mec} A(43.33 \%)$ were the most frequent antibiotic resistance genes.

Conclusions

Powdered packaged medicinal plant and bottle herbal distillate samples may be sources of multidrug resistant-S. aureus, which poses a hygienic threat concerning the consumption of these therapeutic options in Iran. Nevertheless, further research is compulsory to understand other epidemiological features of S. aureus in powdered packaged medicinal plant and bottle herbal distillate samples.

\section{Background}

Medicinal plants and herbal distillates are rich sources of therapeutic agents with high beneficial effects on human health. Recently, the acceptance of medicinal plants and herbal distillates is improved to $20 \%$ of the world population [1]. Moreover, dome kinds of medicinal plants and herbal distillates are mainly used as flavors and additives in the food industries [2]. Furthermore, about 70 to 80 percent of developing countries use herbal and traditional medicine for their primary health care [3]. Diverse kinds of medicinal plants including Zatariamultiflora (Z.multiflora), Saturejabachtiarica (S. bachtiarica), Aloysiacitrodora (A.citrodora), Rosadamascene (R.damascene), Lavandulaangustifolia (L.angustifolia), Alhagi maurorum (A. maurorum), Cichorium intybus (C. intybus), Melissaofficinalis (M.officinalis), Menthapiperita (M.piperita), and Fumariaofficinalis (F.officinalis) are extensively used as antimicrobial, antioxidant, anticancer, anti-neoplasia, food additive, anti-inflammation, wound healing, antiseptic, anti-diabetic, diuretic, expectorant, stimulating the central nervous system, digestive, anti-mutagenic, sedative, analgesic, etc. agents among people al-around the world [1-9]. They also have an export aspect. Thus, it is essential to ensure the quality and safety of these products.

Human involvement in the packaging, powdering, and further procedures of medicinal plants and preparation of bottle herbal distillates caused their unintentional microbial contamination, particularly with those originated from the upper respiratory tract and skin [10]. Previous surveys determined the Staphylococcusaureus (S. aureus) in diverse kinds of medicinal plants and herbal distillates [11]. It is a Gram-positive, catalase-positive, and cocci-shaped bacterium with high attendance on the skin and upper respiratory tract [11]. The bacterium is responsible for plain nosocomial and community-acquired infections, foodborne diseases, and food poisoning [12-15]. Food-related diseases and disorders caused by $S$. aureus are mainly known by abdominal cramps, nausea, vomiting, weakness, and diarrhea, and also toxic shock syndrome (TSS) [11,12]. Foodborne diseases caused by the $S$. aureus bacteria are faced with some difficulties in treatments [13]. Some $S$. aureus isolates mainly resist against diverse antibiotic agents, particularly penicillins, cephems, glycopeptides, aminoglycosides, macrolides, and tetracyclines fluoroquinolones, nitrofurantoins, lincosamides, folate pathway antagonists, phenicols, ansamycins, and even streptogramins $[14,15]$. Epidemiological surveys determined that antibiotic resistance encoding genes are among the main reasons for antibiotic resistance in $S$. aureus bacteria $[16,17]$. Considerable prevalence of the genes that encode resistance toward cephalosporins (b/aCTX-M), penicillins (mecA and blaZ), glycopeptides (vanA and vanB), aminoglycosides (aacA-D), macrolides (ermA, ermB, msrA, and msrB), tetracyclines (tetK and tetM), folate pathway antagonists (dfrA1), ansamycins ( $r p o B)$, lincosamides (linA), fluoroquinolones ( $g y r A$ and $g r l A)$, phenicols $($ fex $A)$ and streptogramins ( $v a t A$ and $v a t B)$ have been reported in the $S$. aureus bacteria recovered from clinical and food samples $[16,17]$. Antibiotic resistant- . aureus strains caused more severe clinical diseases with higher morbidity and mortality rates for a longer period, which accommodate higher economic loads of control, prevention, and treatments [18].

According to people's general perception of medicinal plants' healing effects and herbal distillates, there is a big paradox regarding their microbial contamination. Therefore, it is substantial to assess the microbial quality of medicinal plants and herbal distillates. Thus, the present survey was conducted to assess the prevalence rate and phenotypic and genotypic assessment of $S$. aureus bacteria's antibiotic resistance isolated from different powdered packaged medicinal plant and bottle herbal distillate samples produced in traditional producing units in Iran. 


\section{Materials And Methods}

Sampling

From May 2019 to January 2020, a total of 300 diverse kinds of powdered packaged medicinal plants including Z. multiflora ( $\mathrm{n}=30), S . b a c h t i a r i c a ~(n=30)$, A. citrodora $(\mathrm{n}=30)$ and R.damascene $(\mathrm{n}=30)$ and bottle herbal distillates including L.angustifolia $(\mathrm{n}=30), A$. maurorum $(\mathrm{n}=30), C$. intybus $(\mathrm{n}=30), M$. officinalis $(n=30)$, M.piperita $(n=30)$ and F.officinalis $(n=30)$ were randomly collected from shopping centers, Tehran, Iran. A total of $50 \mathrm{~g}$ samples were collected from each powdered packaged medicinal plant and bottle herbal distillate sample using a sterile laboratory tube. All bootle herbal distillates were produced conventionally in small traditional producing units. Additionally, all collected powdered packaged medicinal plants were dried, powdered, and packed conventionally in traditional production units. Specifications about samples were recorded according to their labels. All samples were directly transferred to the laboratory at $4{ }^{\circ} \mathrm{C}$.

Isolation and identification of S. aureus bacteria

Twenty-five grams of each collected powdered packaged medicinal plant and bottle herbal distillate samples were blended with $225 \mathrm{~mL}$ of buffered peptone water (Merck, Germany). At that time, solutions were homogenized using Stomacher (Interscience, Saint-Nom, France). At that point, five milliliters of the achieved solution was transferred into $50 \mathrm{~mL}$ Trypticase Soy Broth (TSB, Merck, Germany) supplemented with $10 \% \mathrm{NaCl}$ and $1 \%$ sodium pyruvate and incubated for $18 \mathrm{~h}$ at $35^{\circ} \mathrm{C}$. At that moment, a loopful of the culture was transferred into Baird-Parker agar supplemented with egg yolk tellurite emulsion (Merck, Germany) and incubated at $37^{\circ} \mathrm{C}$ for about $24 \mathrm{~h}$. Black shiny colonies enclosed with significant zones identified using biochemical tests including Gram staining, oxidase test, catalase activity, resistance to bacitracin (0.04 U), coagulated test (rabbit plasma), urease activity, glucose $0 / \mathrm{F}$ test, vogesproskaver (Merck, Germany) test, nitrate reduction, phosphatase, deoxyribonuclease (DNase, Merck, Germany) test, mannitol fermentation, hemolysis activity on blood agar (Merck, Germany) and carbohydrate (xylose, sucrose, trehalose and maltose, fructose, lactose, mannose) fermentation tests [19].

\section{Phenotypic analysis of antibiotic resistance of S. aureus isolates}

The phenotypic pattern of antibiotic resistance of $S$. aureus bacteria isolated from powdered packaged medicinal plant and bottle herbal distillate samples was assessed using the disk diffusion method using the Mueller-Hinton agar (Merck, Germany) medium. Ideologies of Clinical and Laboratory Standards Institute (CLSI) were used for this goal [20]. Diverse kinds of antibiotic groups including penicillins (oxacillin (1 $\mu \mathrm{g} / \mathrm{disk})$ and penicillin (10 units/disk)), cephems (cefoxitin $(30 \mu \mathrm{g} /$ disk) and ceftaroline $(30 \mu \mathrm{g} /$ disk)), glycopeptides (vancomycin $(5 \mu \mathrm{g} /$ disk)), aminoglycosides (gentamicin (15 $\mu \mathrm{g} /$ disk)), macrolides (azithromycin $(15 \mu \mathrm{g} /$ disk) and erythromycin $(15 \mu \mathrm{g} /$ disk)), tetracyclines (tetracycline $(30 \mu \mathrm{g} / \mathrm{disk})$ and doxycycline $(30 \mu \mathrm{g} / \mathrm{disk}))$, fluoroquinolones (ciprofloxacin $(5 \mu \mathrm{g} /$ disk) and levofloxacin $(5 \mu \mathrm{g} /$ disk)), nitrofurantoins (nitrofurantoin $(300 \mu \mathrm{g} / \mathrm{disk})$ ), lincosamides (clindamycin $(2 \mu \mathrm{g} / \mathrm{disk})$ ), folate pathway antagonists (trimethoprim-sulfamethoxazole $(1.25 / 23.75 \mu \mathrm{g} / \mathrm{disk}))$, phenicols (chloramphenicol (30 $\mu \mathrm{g} / \mathrm{disk})$ ), ansamycins (rifampin (5 $\mu \mathrm{g} / \mathrm{disk}))$ and streptogramins (quinupristin-dalfopristin ( $15 \mu \mathrm{g} /$ disk)) were applied for this goal (Oxoid, UK). The method was performed using the way designated previously [20]. S. aureus ATCC 25923 was used as control.

\section{DNA extraction and quality examination}

S. aureus isolates were sub-cultured on TSB media (Merck, Germany) and incubated for $48 \mathrm{~h}$ at $37^{\circ} \mathrm{C}$. Genomic DNA was extracted from MRSA colonies using the DNA extraction kit (Thermo Fisher Scientific, St. Leon-Rot, Germany). Guidelines of the producing company were performed for this purpose. Purity (A260/A280) of extracted DNA was examined by the NanoDrop device (NanoDrop, Thermo Scientific, Waltham, MA, USA). The quality of extracted DNA was examined using electrophoresis on $2 \%$ agarose gel.

Genotypic analysis of antibiotic resistance of S. aureus isolates

The genotypic pattern of antibiotic resistance of $S$. aureus bacteria isolated from powdered packaged medicinal plant and bottle herbal distillate samples was assessed by PCR technique [21-28]. Distribution of the genes that encode resistance against cephems (blaCTX-M), penicillins (blaZ and mecA), glycopeptides (vanA and vanB), aminoglycosides (aacA-D), macrolides (ermA, ermB, msrA and msrB), tetracyclines (tetK and tetM), folate pathway antagonists (dfrA1), ansamycins $(r p o B)$, lincosamides (linA), fluoroquinolones ( $g y r A$ and $g r / A)$, phenicols $(f e x A)$, and streptogramins (vat $A$ and vatB) antibiotics were studied. Table 1 discloses the PCR circumstances used for the detection of antibiotic resistance genes amongst the MRSA strains. A programmable DNA thermo-cycler (Eppendorf Mastercycler 5330, Eppendorf-Nethel-Hinz GmbH, Hamburg, Germany) was applied for this goal. Amplified products were analyzed by electrophoresis (120 V/208 mA) in 2.5\% agarose gel. The gel was stained with $0.1 \%$ ethidium bromide $(0.4 \mu \mathrm{g} / \mathrm{ml}$, (Thermo Fisher Scientific, St. Leon-Rot, Germany). The UVI doc gel documentation systems (Grade GB004, Jencons PLC, London, UK) was used to assess the results of the PCR.

\section{Statistical analysis}

Statistical analysis was done using the SPSS 21.0 statistical software (SPSS Inc., Chicago, IL, USA). Chi-square test and Fisher's exact two-tailed test were used to assess any significant relationship between the phenotypic and genotypic properties of antibiotic resistance of the $S$. aureus bacteria isolated from powdered packaged medicinal plant and bottle herbal distillate samples. $P$-value $<0.05$ was considered as significant statistical level.

\section{Results}

Contamination rate of examined samples with S. aureus

The present survey was conducted to assess the prevalence and phenotypic and genotypic examination of $S$. aureus bacteria's antibiotic resistance isolated from diverse kinds of powdered packaged medicinal plant and bottle herbal distillate samples.

Page 3/17 
Table 2 shows the contamination rate of diverse powdered packaged medicinal plant and bottle herbal distillate samples with $S$. aureus. Thirty out of threehundred (10\%) medicinal plant and herbal distillate samples were contaminated with $S$. aureus. The contamination rates of powdered packaged medicinal plant and bottle herbal distillate samples were $8.33 \%$ and $11.11 \%$, respectively. A.citrodora (10\%) and R.damascene (10\%) had the highest contamination rate with S. aureus amongst all examined powdered packaged medicinal plants, while S.bachtiarica (6.66\%) and Z.multiflora (6.66\%) had the lowest. A. maurorum (16.66\%) had the highest contamination rate with S. aureus amongst all examined bottle herbal distillates, while M.officinalis (6.66\%) and M.piperita (6.66\%) had the lowest. Statistically significant difference was obtained for the contamination rate of $S$. aureus between powdered packaged medicinal plants and bottle herbal distillates $(P<0.05)$. Additionally, statistically significant differences were obtained between examined samples and the contamination rate with S. aureus $(P<0.05)$.

Phenotypic properties of antibiotic resistance

Table 3 shows the phenotypic pattern of antibiotic resistance of $S$. aureus bacteria isolated from diverse kinds of powdered packaged medicinal plant and bottle herbal distillate samples. S. aureus bacteria exhibited the highest prevalence of resistance toward penicillin (93.33\%), tetracycline (90\%), gentamicin (86.66\%), erythromycin (70\%), trimethoprim-sulfamethoxazole (63.33\%), ciprofloxacin (53.33\%), oxacillin (50\%), and cefoxitin (50\%) antibiotic agents. Reversely, S. aureus bacteria harbored the lowest prevalence of resistance toward chloramphenicol (20\%), nitrofurantoin (36.66\%), quinupristin-dalfopristin (40\%), azithromycin (43.33\%), doxycycline (43.33\%), and rifampin (43.33\%) antibiotic agents. S. aureus bacteria isolated from bottle herbal distillates harbored a higher and more diverse prevalence of resistance toward examined antibiotic agents $(P<0.05)$. Additionally, a statistically significant difference was obtained between types of examined samples and prevalence of antibiotic resistance $(P<0.05)$.

\section{Prevalence of multidrug resistant-S. aureus}

Figure 1 shows the prevalence of multidrug resistant-S. aureus bacteria amongst all examined samples. All of the $S$. aureus bacteria isolated from powdered packaged medicinal plant and bottle herbal distillate samples harbored resistance to at least one of the examined antibiotic agents. The prevalence of resistance toward at least five antibiotic agents was $46.66 \%$. Findings revealed that $13.33 \%$ of the $S$. aureus isolates harbored resistance toward more than seven antibiotic agents.

\section{Genotypic properties of antibiotic resistance}

Table 4 shows the genotypic pattern of antibiotic resistance of $S$. aureus bacteria isolated from diverse kinds of powdered packaged medicinal plant and bottle herbal distillate samples. The most prevalent antibiotic resistance genes amongst the $S$. aureus bacteria isolated from examined powdered packaged medicinal plant and bottle herbal distillate samples were blaZ (63.33\%), tetK (60\%), ermA (46.66\%), $m s r A(43.33 \%)$, aacA-D (43.33\%), and $m e c A(43.33 \%)$. Distribution of $m s r B(6.66 \%), \operatorname{erm} B(10 \%), \operatorname{van} B(13.33 \%), f e x A(13.33 \%), r p o B(20 \%)$, and $v a t B(20 \%)$ were lower than other examined antibiotic resistance genes. $S$. aureus bacteria isolated from bottle herbal distillates harbored the higher and more diverse distribution of antibiotic resistance genes $(P<0.05)$. Additionally, a statistically significant difference was obtained between types of examined samples and distribution of antibiotic resistance genes $(P<0.05)$. Statistical significant differences were obtained between the distribution of mecA and blaZ $(P<0.05)$, vanA and van $B(P<0.05)$, vat $A$ and vatB $(P<0.05)$, erm $A$ and $\operatorname{erm} B(P<0.05), m s r A$ and $m s r B(P<0.05)$ and tetK and tetM $(P<0.05)$ antibiotic resistance genes. There was no significant difference between the distribution of fluoroquinolones resistance genes $(P>0.05)$.

\section{Discussion}

Extensive diversity of microbial contaminants might accompany medicinal plants. Unavoidably, the microbial background relies on numerous ecological factors and employs an imperative influence on herbal products' safety and quality. The microbial contaminants of herbal products are simply transferred through air, soil, animal- and human-based fertilizers, and finally infected staff and workers producing units [10]. Otherwise, a host of agricultural, environmental, industrial, and urban factors, together with less than good harvesting, storage, and processing procedures, are additional reasons for contamination in herbal products [10]. In these cases, medicinal plants and herbal products with confirmed therapeutic effects not only do not improve the patient's condition, but also lead to diverse kinds of foodborne diseases and disorders. Thus, assess the microbial quality of herbal products is essential as an imperative public health matter.

The present survey was conducted to assess the prevalence and antibiotic resistance properties of the $S$. aureus bacteria isolated from diverse kinds of powdered packaged medicinal plant and bottle herbal distillate samples produced in traditional circumstances in Iran. Findings of the current investigation disclosed that the contamination rate of examined raw medicinal plants and herbal distillates with $S$. aureus was $10 \%$. Some of the examined samples, such as Z.multiflora (6.66\%) and S.bachtiarica (6.66\%) powdered packaged medicinal plants and M.officinalis (6.66\%), and M.piperita (6.66\%) bottle herbal distillates had the lower contamination rate with $S$. aureus. One of the probable reasons for this finding is the high antimicrobial effects of Z.multiflora, S.bachtiarica, M.officinalis, M.piperita, and C. intybus against diverse kinds of bacteria [29-32]. Thus, S. aureus' growth and survival have been decreased and even stopped in these medicinal plants and their derived products.

S. aureus is most expected to originate from herbal products' contact with food handlers throughout harvesting, processing, and storage, and its absence reflects the acceptable hygiene practices. Our findings also revealed that herbal distillates had a higher contamination rate with $S$. aureus than medicinal plants. The probable reason for this finding is maybe the extinction of $S$. aureus bacteria during medicinal plants' drying process. Additionally, the processing of herbal distillates requires more human involvement and manipulation. Thus, the transmission of $S$. aureus bacteria from the infected staff and workers producing units to the herbal distillates may be another reason for the high prevalence of $S$. aureus in these samples. Despite the high importance of the topic, many limited surveys have been conducted in this field. A survey concocted by Sousa Lima et al. (2020) [33] disclosed that the prevalence of $S$. aureus bacteria amongst the homemade and commercial herbal medicine samples (Lippia alba, Peumus boldus Molina, Cymbopogon citratus, Carapa guianensis, 
Copaifera langsdorffii, Stryphnodendron adstringens, Costus spicatus, and Arrabidaea chica) was $88.50 \%$ and $23.50 \%$, respectively. Kaume et al. (2012) [34] described that the prevalence of $S$. aureus amongst the medicinal plants marketed to patients suffered from the HIV-infection in Kenya was $71.40 \%$, which was entirely higher than our findings. Esimone et al. (2007) [35] also reported that the prevalence of $S$. aureus amongst the medicinal plants sold in Nigeria was $8.70 \%$. Reversely, No S. aureus strains bacteria were recovered from the medicinal plants in the study conducted in South-Africa [36]. Ideh et al. (2019) [37] described that the Staphylococcal microbial load of some kinds of medicinal plants in Nigeria had ranged between $1.50 \times 10^{5}$ to $6.75 \times 10^{6}$ Colony Forming Unit (CFU)/g, which was entirely higher than the limit microbial load introduced by the World Health Organization (WHO) (10 4 CFU/g) [38]. Similarly, a high contamination rate of herbal products with $S$. aureus and other Staphylococcal species has been reported previously from Bangladesh [39], Korea [40], Nigeria [41, 42], Germany [43], Sudan [44], Saudi Arabia [45], Benin [46], and Ethiopia [47]. Likewise, high microbial contamination of some kinds of medicinal plants other than S. aureus has been reported in diverse researches conducted on Iran [48, 49], Bangladesh [50], Tanzania [51], Kenya [52, 53], Malaysia [54], Iraq [55], Poland [56, 57], Italy [58], Saudi Arabia [59], Thailand [60], South Africa [61], Pakistan [62], and United States [63]. One possible reason for the presence of diverse bacteria, particularly $S$. aureus, in powdered packaged medicinal plant and bottle herbal distillate samples in their proper intrinsic factors such as pH. The $\mathrm{pH}$ levels of examined powdered packaged medicinal plant and bottle herbal distillate samples ranged from 3.5 to 9.5 , facilitating luxuriant growth and survival of most bacterial species [64]. The contamination rate of herbal product samples with $S$. aureus vary between diverse researches. The difference in data advises that time, season, place of sampling, method of sampling, types of samples, and even laboratory techniques applied in research may affect surveys' outcomes. Moreover, difference hygienic levels of producing units of herbal products may affect the prevalence of $S$. aureus in diverse investigations. Compared to the results of other scientists, the comparatively low rate of $S$. aureus isolation was reported in our survey. Relatively low contamination rate may be due to natural antimicrobials and possibly to a commonly good hygiene situation, however high contamination rate may specify less favourable hygienic circumstances.

The second part of the present survey was performed on the antibiotic resistance properties of $S$. aureus isolates. Findings revealed that $S$. aureus bacteria displayed the highest prevalence of resistance toward penicillin, tetracycline, gentamicin, erythromycin, trimethoprim-sulfamethoxazole, ciprofloxacin, and cefoxitin antibiotic agents, which was accompanied by high prevalence of blaZ and mecA, tetK, aacA-D, msrA and ermA, gyrA, dfrA1, and blaCTX-M antibiotic resistance encoding genes, respectively. Thus, the phenotypic presence of antibiotic resistance was confirmed by the genotypic presence of antibiotic resistance encoding genes. Furthermore, the presence of multidrug resistant-S. aureus was found in some isolates. Irregular and unauthorizing antibiotic agents' prescription is the probable reason for the high prevalence of resistance and high distribution of antibiotic resistance genes. Findings disclosed that some $S$. aureus bacteria exhibited a higher prevalence of resistance toward antibiotic agents used to treat human clinical infections, which can indirectly signify that they may transmit from infected staff and workers of producing units of medicinal plants and herbal distillates. Reversely, some others exhibited a higher prevalence of resistance toward antibiotics used mostly for treatment of animal infections, which can indirectly demonstrate that they may transmit from animal species, particularly in using animal-based fertilizers and polluted water for growth and irrigation of medicinal plants. The presence of resistance toward chloramphenicol (20\%), which was assisted with attendance of fexA antibiotic encoding gene (13.33\%) may reflect using of poultry-based fertilizers for the growth of medicinal plants since chloramphenicol is a common antibiotic choice in Iranian poultry farms [65, 66]. According to the literature, the present survey is the first report of the phenotypic and genotypic assessments of antibiotic resistance amongst the $S$. aureus bacteria isolated from powdered packaged medicinal plants and bottle herbal distillate samples globally. Braide et al. (2013) [67] stated that the $S$. aureus bacteria isolated from herbal remedies were susceptible to ofloxacin, chloramphenicol, gentamicin, pefloxacin, ciprofloxacin, and erythromycin antibiotic agents. Ngemenya et al. (2019) [68] described that the $S$. aureus strains isolated from herbal remedies in Cameroon were resistant against five classes of examined antibiotic agents (amikacin, cefotaxime, cefuroxime, imipenem, trimethoprim, and ceftriaxone). Similarly, Yesuf et al. (2016) [47] reported that the S. aureus strains isolated from medicinal herbal products in Ethiopia harbored the high prevalence of resistance toward ampicillin (80\%), penicillin (60\%), amoxicillin (40\%), amoxicillinclavulanic acid (40\%), chloramphenicol (40\%), and cloxacillin, (30\%). Similar pattern of resistance of $S$. aureus bacteria has been described toward penicillins [66, 69-73], tetracyclines [66, 69-71], aminoglycosides [66, 69-73], macrolides [66, 69-73], cephems [66, 69-73], fluoroquinolones [66, 69-73], and folate pathway antagonists [66, 69-73] antibiotic groups. A similar resistance pattern of the $S$. aureus bacteria was reported previously [74, 75]. Differences in the opinion of medical and veterinary practitioners in an antibiotic prescription, observation of ethics and rules in the use of antibiotics, availability or lack of antibiotics, and their prices are probable reasons for differences found in the prevalence of resistance of $S$. aureus strains in numerous investigations. Diverse researches have been conducted to appraise the antibiotic resistance properties of $S$. aureus. Most of them reported the confirmation of phenotypic pattern of antibiotic resistance by the presence of diverse antibiotic encoding genes $[16,66,76,77]$ High distribution of blaZ, mecA, tetK, aacA-D, msrA, ermA, gyrA, dfrA1, and blaCTX-M antibiotic resistance encoding genes in the $S$. aureus bacteria isolated from diverse kinds of food samples and also human clinical infections have been reported from Iran [66, 76, 78], India [79], Georgia [72], Nigeria [80], Germany [81], Egypt [82], and Switzerland [83]. Comparable to our research, higher prevalence of $m s r A$ than $\operatorname{msr} B[66,76,78,84]$, erm $A$ than $\operatorname{erm} B[66,76,78,84,85]$, tetK than $\operatorname{tet} M[66,76,78,84]$ vat $A$ than vatB $[66,76,78,84]$, vanA than van $B$ $[66,76,78,84,85]$ and $g y r A$ than $g r l A[66,76,84]$ antibiotic resistance encoding genes has been reported in recent years. Our findings were also disclosed a higher prevalence of phenotypic profile of resistance than genotypic profile. For instance, all of the penicillin-resistant $S$. aureus bacteria didn't harbored blaZ and $m e c A$ antibiotic resistance genes. This matter was also existed for other antibiotic agents and resistance genes. This finding is maybe owing to the fact that presence of antibiotic resistance genes is one of the known procedures for occurrence of antibiotic resistance in bacteria. In the other hand, several mechanisms have been identified to induce antibiotic resistance in bacteria including reduced permeability of bacteria to antibiotics, efflux antibiotic's active pumps to out of the bacterial cell, change in antibiotic target site, inactivation of antibiotics through hydrolysis or changes in their structure, occurrence of genetic mutations and access of bacteria to the secondary metabolic pathways that compensate the antibiotic-inhibited reactions.

Findings also revealed the high prevalence of multidrug resistant-S. aureus strains amongst medicinal plants and herbal distillates. Similarly, a high prevalence of multidrug-resistant bacteria has been reported in herbal product samples in Kenya [86], Cameroon [68], and Ethiopia [47]. Additionally, the high distribution of multidrug resistant-S. aureus strains have been described in clinical specimens and foodstuff samples collected from China [87], United States [88], and Kuwait [89]. Altogether, the high prevalence of antibiotic resistance in S. aureus, which was accompanied by the high distribution of antibiotic resistance genes and the presence of multidrug resistance, disclosed a pressing public health issue regarding the consumption of powdered packaged medicinal plants and bottle herbal distillate samples. 


\section{Conclusions}

Put together, an existing survey is the first report of prevalence and phenotypic evaluation of antibiotic resistance of $S$. aureus bacteria isolated from $Z$. multiflora, S.bachtiarica, A.citrodora and R.damascene powdered packaged medicinal plants and L.angustifolia, A. maurorum, C. intybus, M. officinalis, M.piperita and F.officinalis bottle herbal distillates, globally. Additionally, it was the first report of detection of antibiotic resistance genes amongst the $S$. aureus strains isolated from diverse kinds of powdered packaged medicinal plants and bottle herbal distillate samples globally. Findings disclose that powdered packaged medicinal plants and particularly bottle herbal distillates are potential sources of multidrug resistant-S. aureus. Bottle herbal distillates harbored a higher prevalence of $S$. aureus isolates and also higher antibiotic resistance. High prevalence of resistance of $S$. aureus bacteria toward penicillin, tetracycline, gentamicin, erythromycin, trimethoprim-sulfamethoxazole, ciprofloxacin, and cefoxitin antibiotic agents was observed, which was also accompanied by the high prevalence of blaZ and mecA, tetK, aacA-D, msrA ans ermA, gyrA, dfrA1 and blaCTX-M antibiotic resistance encoding genes, respectively. The prevalence of resistance toward human-based antibiotics and animal-based antibiotics can indirectly show $S$. aureus isolates' origin. It seems that penicillin, tetracycline, gentamicin, erythromycin, trimethoprim-sulfamethoxazole, ciprofloxacin, and cefoxitin are not effective therapeutic agents in the cases of $S$. aureus foodborne diseases at this time in Iran. Types of examined samples had high effects on the prevalence and antibiotic resistance properties of $S$. aureus strains. Traditional producing and processing centers of powdered packaged medicinal plants and bottle herbal distillates can be severely contaminated with foodborne pathogens, particularly $S$. aureus; the maintenance of their hygiene, regular microbiological monitoring of these samples, implementation of good manufacturing practices and a food safety system such as the Hazzard Analysis Critical Control Points (HACCP) system are essential to minimize the risk to the consumer. Furthermore, using high quality raw materials in production of powdered packaged medicinal plants and bottle herbal distillate samples, prevention from cross-contamination and antibiotic prescription based on disk diffusion outcomes can diminish the risk of transmission of multidrug resistant-S. aureus bacteria from powdered packaged medicinal plants and bottle herbal distillate samples to the human population. On the basis of these observations, we recommend that attention should be paid by governments and individuals to prevent the further spread of multidrug resistant-S. aureus. However, supplementary surveys are essential to determine more epidemiological features of the multidrug resistant-S. aureus bacteria in powdered packaged medicinal plants and bottle herbal distillate samples.

\section{Abbreviations}

S. aureus: Staphylococcus aureus; PCR: Polymerase Chain Reaction; SPSS: Statistical Package for the Social Sciences

\section{Declarations}

\section{Ethics approval and consent to participate}

The present investigation was confirmed by the ethical supervision of Scientific Research of the Alborz, University of Medical Sciences, Karaj, Iran (No 3607614). Sampling licenses were taken by Dr. Bahareh Tavakoli-Far and Dr. Zohreh Mashak (Ref Number 3607614).

\section{Consent for publication}

There was no consent for publication.

\section{Availability of data and material}

All data generated or analyzed throughout this research are included in this published article.

\section{Competing interests}

The authors declare that they have no competing interests

\section{Funding}

This work was supported by the Faculty of Medicine, Alborz University of Medical Sciences, Karaj, Iran (No 3607614).

\section{Authors' contributions}

BT designed the study and carried out the culture-based identification and PCR genetic alignment. ZM supported the study and carried out the sample collection, disk diffusion and statistical analysis. BT $\mathrm{M}$ carried out the writing and drafting of the manuscript. All authors read and approved the final manuscript.

\section{Acknowledgments}

The authors would like to thank the Alborz University of Medical Sciences laboratory practitioners for their practical supports.

\section{Authors' information}

${ }^{1}$ Department of Food Hygiene, Karaj Branch, Islamic Azad University, Karaj, Iran (Mashak@kiau.ac.ir); ${ }^{2}$ Dietary Supplements and Probiotic Research Center, Alborz University of Medical Sciences, Karaj, Iran (B.tavakolifar@abzums.ac.ir).

\section{References}


1. Fitzgerald M, Heinrich M, Booker A. Medicinal Plant Analysis: A Historical and Regional Discussion of Emergent Complex Techniques. Front Pharma. 2019;10.

2. Jamshidi-Kia F, Lorigooini Z, Amini-Khoei H. Medicinal plants: Past history and future perspective. J Herb Pharma. 2018;7(1).

3. Ekor M. The growing use of herbal medicines: issues relating to adverse reactions and challenges in monitoring safety. Front Pharma. $2014 ; 4177$.

4. Sharafzadeh S, Alizadeh O. Some medicinal plants cultivated in Iran. J Appl Pharm Sci. 2012;2(1):134-7.

5. Kumar S, Paul S, Walia YK, Kumar A, Singhal P. Therapeutic potential of medicinal plants: a review. J. Biol. Chem. Chron. 2015;1(1):46-54.

6. Anand U, Jacobo-Herrera N, Altemimi A, Lakhssassi N. A Comprehensive Review on Medicinal Plants as Antimicrobial Therapeutics: Potential Avenues of Biocompatible Drug Discovery. Metabolites. 2019;9(11):258.

7. Dehkordi FS, Tirgir F, Valizadeh Y. Effects of Guajolß ointment synthesized from medicinal smoke condensate of jennet feces on burn wound healing on Wistar rat. Vet Res Forum. 2017;8(3):215.

8. Akinyemi O, Oyewole S, Jimoh K. Medicinal plants and sustainable human health: a review. Horticulture International Journal. 2018;2(4):194-195.

9. Khan AM, Rezazadeh S. Review on Iranian medicinal plants with antioxidant properties. J Med Plants. 2010;9(35).

10. Kneifel W, Czech E, Kopp B. Microbial contamination of medicinal plants-a review. Planta Medica. 2002;68(01):5-15.

11. Madahi H, Rostami F, Rahimi E, Dehkordi FS. Prevalence of enterotoxigenic Staphylococcus aureus isolated from chicken nugget in Iran. Jundishapur $\mathrm{J}$ Microbiol. 2014;7(8).

12. Abdolmaleki Z, Mashak Z, Safarpoor Dehkordi F. Molecular and Virulence Characteristics of Methicillin-Resistant Staphylococcus aureus Bacteria Recovered From Hospital Cockroaches. Jundishapur J Microbiol. 2019;12(12).

13. Kadariya J, Smith TC, Thapaliya D. Staphylococcus aureus and staphylococcal foodborne disease: an ongoing challenge in public health. BioMed Res Int. $2014 ; 2014$

14. Foster TJ. Antibiotic resistance in Staphylococcus aureus. Current status and future prospects. FEMS Microbiol Rev. 2017;41(3):430-449.

15. Chambers HF, DeLeo FR. Waves of resistance: Staphylococcus aureus in the antibiotic era. Nature Rev Microbiol. 2009;7(9):629-641.

16. Li S-M, Zhou Y-F, Li L, Fang L-X, Duan J-H, Liu F-R, Liang H-Q, Wu Y-T, Gu W-Q, Liao X-P. Characterization of the multidrug resistance gene cfr in methicillinresistant Staphylococcus aureus (MRSA) strains isolated from animals and humans in China. Front Microbiol. 2018;92925.

17. Asinamai Athliamai B, Olabode Mayowa P, Muhammad AA, Mohammed DG. Staphylococcus aureus: A Review of Antimicrobial Resistance Mechanisms. Vet Sci Res Rev. 2018 4(2):43.

18. Zhen X, Lundborg CS, Sun X, Hu X, Dong H. Economic burden of antibiotic resistance in ESKAPE organisms: a systematic review. Antimicrob Resist Infect Control. 2019;8(1):137.

19. Patel R, Kumar R, Savalia C, Patel N. Isolation of Staphylococcus aureus from Raw Cattle Milk and their Drug Resistance Pattern. Int. J. Curr. Microbiol. App. Sci. 2018;7(2):836-840.

20. CLSI. Performance Standards for Antimicrobial Susceptibility Testing; Twenty-eight Informational Supplement. In CLSI document M100. 2018.

21. Kehrenberg C, Schwarz S. Florfenicol-chloramphenicol exporter gene fexA is part of the novel transposon Tn558. Antimicrobial agents and chemotherapy. 2005;49(2):813-815.

22. Strommenger B, Kettlitz C, Werner G, Witte W. Multiplex PCR assay for simultaneous detection of nine clinically relevant antibiotic resistance genes in Staphylococcus aureus. J Clinical Microbiol. 2003;41(9):4089-4094.

23. Lina G, Quaglia A, Reverdy M-E, Leclercq R, Vandenesch F, Etienne J. Distribution of genes encoding resistance to macrolides, lincosamides, and streptogramins among staphylococci. Antimicrob Agent Chem. 1999;43(5):1062-1066.

24. Aboshkiwa M, Rowland G, Coleman G. Nucleotide sequence of the Staphylococcus aureus RNA polymerase rpoB gene and comparison of its predicted amino acid sequence with those of other bacteria. Biochimica et Biophysica Acta (BBA)-Gene Structure and Expression. 1995;1262(1):73-78.

25. Schmitz F-J, Jones ME, Hofmann B, Hansen B, Scheuring S, Lückefahr M, Fluit A, Verhoef J, Hadding U, Heinz H-P. Characterization of grlA, grlB, gyrA, and gyrB mutations in 116 unrelated isolates of Staphylococcus aureus and effects of mutations on ciprofloxacin MIC. Antimicrob Agent Chem. 1998;42(5):1249-1252.

26. Roberts MC, Sutcliffe J, Courvalin P, Jensen LB, Rood J, Seppala H. Nomenclature for macrolide and macrolide-lincosamide-streptogramin B resistance determinants. Antimicrob Agent Chem. 1999;43(12):2823-2830.

27. Pagani L, Dell'Amico E, Migliavacca R, D'Andrea MM, Giacobone E, Amicosante G, Romero E, Rossolini GM. Multiple CTX-M-type extended-spectrum $\beta$ lactamases in nosocomial isolates of Enterobacteriaceae from a hospital in northern Italy. J Clinical Microbiol. 2003;41(9):4264-4269.

28. Clark N, Cooksey R, Hill B, Swenson J, Tenover F. Characterization of glycopeptide-resistant enterococci from US hospitals. Antimicrobial Agents and Chemotherapy. 1993;37(11):2311-2317.

29. Mahboubi M, Kazempour N. In vitro antimicrobial activity of some essential oils from Labiatae family. J Essential Oil Bear Plants. 2009;12(4):494-508.

30. Saeidi S, Mohsenbeygi M, Roustakhiz J, Javadian F, Hassanshahian M. Antimicrobial and anti-biofilm effects of Mentha piperita and Zataria multiflora on Pathogenic Bacteria. J Med Bacteriol. 2019;8(1-2):37-44.

31. Rabbani M, Etemadifar Z, Karamifard F, Borhani MS. Assessment of the antimicrobial activity of Melissa officinalis and Lawsonia inermis extracts against some bacterial pathogens. Compar Clin Patho. 2016;25(1):59-65.

32. Heidari-Sureshjani M, Tabatabaei-Yazdi F, Alizadeh-Behbahani B, Mortazavi A. Antimicrobial effect of aqueous, ethanol, methanol and glycerin extracts of Satureja bachtiarica on Streptococcus pyogenes, Pseudomonas aeruginosa and Staphylococcus epidermidis. Zahedan J Res Med Sci. 2015;17(7). 
33. de Sousa Lima CM, Fujishima MAT, de Paula Lima B, Mastroianni PC, de Sousa FFO, da Silva JO. Microbial contamination in herbal medicines: a serious health hazard to elderly consumers. BMC Complement Med Therapies. 2020;20(1):17.

34. Kaume L, Foote JC, Gbur EE. Microbial contamination of herbs marketed to HIV-infected people in Nairobi (Kenya). South African J Sci. 2012;108(9-10):14.

35. Esimone C, Oleghe P, Ibezim E, Okeh C, Iroha I. Susceptibility-resistance profile of micro-organisms isolated from herbal medicine products sold in Nigeria. African J Biotech. 2007;6(24).

36. Van Vuuren S, Williams VL, Sooka A, Burger A, Van der Haar L. Microbial contamination of traditional medicinal plants sold at the Faraday muthi market, Johannesburg, South Africa. South African J botany. 2014;9495-100.

37. Ideh JE, Ogunkunle AT. User frequency and microbial contaminants of traditional oral powdered herbal formulations in Ogbomoso, Nigeria. J Med Plant Eco Develop. 2019;3(1):1-9.

38. Organization WH.Quality control methods for medicinal plant materials. World Health Organization1998.

39. Sharmin M, Nur IT, Acharjee M, Munshi SK, Noor R. Microbiological profiling and the demonstration of in vitro anti-bacterial traits of the major oral herbal medicines used in Dhaka Metropolis. SpringerPlus. 2014;3(1):739.

40. Ham H. Distributions of Listeria spp., Bacillus spp., Enterococcus spp., Staphylococcus spp., and Coliforms Isolated from Agricultural Herb Products from the Market. J Bacteriol Virol. 2017;47(4):171-178.

41. Ezenobi NO, Ogbu HI, Kpea DT. Antimicrobial susceptibility of common pathogens isolated from paediatric cough syrups in Port Harcourt metropolis, Nigeria. European J Pharma Med Res. 2019;6(1):562-571.

42. Onyemelukwe Ngozi F, Chijioke Olive U, Dozie-Nwakile Ogechuckwu OSJ. Microbiological, Parasitological And Lead Contamination Of Herbal Medicines Consumed In Enugu, Nigeria. Biomed Res. 2019;30(6):828-833.

43. Becker B, Stoll D, Schulz P, Kulling S, Huch M. Microbial contamination of organically and conventionally produced fresh vegetable salads and herbs from retail Markets in Southwest Germany. Foodborne Patho Dis. 2019;16(4):269-275.

44. Abdelkarim M, Eithar karar MA, Aleman M. Assessment of bacterial contamination of some medicinal plants available in sudanese local market. IJIPSR 2016;4(11):1152-1161.

45. Alwakeel SS. Microbial and heavy metals contamination of herbal medicines. Res J Microbiol. 2008;3(12):683-691.

46. Adounkpe FM, Allabi AC, Baba-Moussa F, Gbegbe M, Keke M, Moutairou K. Microbiological quality assessment of aqueous herbal teas sold in Cotonou, Benin. Int J Herbal Med. 2017;5(3):121-126.

47. Yesuf A, Wondimeneh Y, Gebrecherkos T, Moges F. Occurrence of Potential Bacterial Pathogens and Their Antimicrobial Susceptibility Patterns Isolated from Herbal Medicinal Products Sold in Different Markets of Gondar Town, Northwest Ethiopia. Int J Bacteriol. 2016;201611.

48. Alavi I, Zahedi M, Zahedi M, Ghasemi Pirbalouti A, Rahimi E, Momtaz H. Evaluating the microbial contamination of some Iranian dried medicinal plants and distillates. Int J Epidem Res. 2017;4(2):118-124.

49. Enayatifard R, Asgarirad H, Kazemi-Sani B. Microbial quality of some herbal solid dosage forms. African J Biotech. 2010;9(11):1701-1705.

50. Fatema K, Chakraborty SR, Sultana T, Rahman MM, Kamali NM, Das KK, Noor R. Assessment of microbiological quality of the pediatric oral liquid drugs. J Pharmacogn Phytochem. 2014;3(1).

51. Walther C, Marwa KJ, Seni J, Hamis P, Silago V, Mshana SE, Jande M. Microbial contamination of traditional liquid herbal medicinal products marketed in Mwanza city: magnitude and risk factors. Pan African Med J. 2016;23(1).

52. Onyambu MO, Chepkwony HK, Thoithi GN, Ouya GO, Osanjo GO. Microbial quality of unregulated herbal medicinal products in Kenya. African Journal of Pharmacology and Therapeutics. 2013;2(3).

53. Ngari FW, Gikonyo NK, Wanjau RN, Njagi N. Investigation of selected pathogenic microorganisms and toxic elements in herbal materials used in management of oral health in Nairobi County, Kenya. J App Env Bio Sci. 2013;3(12):1-7.

54. Rahman MZ, Islam SS, Chowdhury A, Subramaniam S. Identification and prevention of microbial contaminants of potato culture in temporary immersion bioreactor (TIB) system. Malaysian J Microbiol. 2017;13(4):289-297.

55. Abaas IS, Mohammed HR, Majeed AH. The microbial contamination study of some herbal cosmatics products used in traditional medicine in Iraq. karbala journal of pharmaceutical sciences. 2013;(6):132-140.

56. Ratajczak M, Kubicka M, Kamińska D, Sawicka P, Długaszewska J. Microbiological quality of non-sterile pharmaceutical products. Saudi Pharma J. 2015;23(3):303-307.

57. Gutarowska B, Skóra J, Stępień Ł, Szponar B, Otlewska A, Pielech-Przybylska K. Assessment of microbial contamination within working environments of different types of composting plants. J Air Waste Manag Associat. 2015;65(4):466-478.

58. Vitullo M, Ripabelli G, Fanelli I, Tamburro M, Delfine S, Sammarco ML. Microbiological and toxicological quality of dried herbs. Letter App Microbiol. 2011;52(6):573-580.

59. Al Kahtani MD. Identification and Quantification of Microbial Contaminations Present in Herbal Medicines Commonly Consumed by Women in Riyadh, Saudi Arabia. J Agri Chem Env. 2016;6(1):83-92.

60. Rangsipanuratn W, Kammarnjassadakul P, Janwithayanuchit I, Paungmoung P, Ngamurulert S, Sriprapun M, Yangen S, Soottitantawat V, Sandee A. Detection of microbes, aflatoxin and toxic heavy metals in Chinese medicinal herbs commonly consumed in Thailand. Pharm Sci Asia. 2017;44 (3):162171. 
61. Famewo EB, Clarke AM, Afolayan AJ. Identification of bacterial contaminants in polyherbal medicines used for the treatment of tuberculosis in Amatole District of the Eastern Cape Province, South Africa, using rapid 16S rRNA technique. J Health Populat Nutr. 2016;35(1):27.

62. Imran ZP, Bawa MY, Daniyal M, Usmanghani K. Quality control of polyherbal drugs for the detection of microbial agents. RADS J Pharma Pharmaceut Sci. 2017;5(3):51-56.

63. Tournas V, Katsoudas EJ. Microbiological quality of various medicinal herbal teas and coffee substitutes. Microbiol Insights. $2008 ; 1 \mathrm{MBI}$. S943.

64. Lacoma T.Factors that affect growth of microorganisms, viewed 12 March 2019, from https://sciencing.com/three-conitions-ideal-bacteria-growth9122.html. 2018.

65. Hemmatinezhad B, Khamesipour F, Mohammadi M, Safarpoor Dehkordi F, Mashak Z. Microbiological Investigation of O-Serogroups, Virulence Factors and Antimicrobial Resistance Properties of Shiga Toxin-Producing E scherichia Coli Isolated from Ostrich, Turkey and Quail Meats. J Food Safety. 2015;35(4):491-500.

66. Safarpoor Dehkordi F, Gandomi H, Akhondzadeh Basti A, Misaghi A, Rahimi E. Phenotypic and genotypic characterization of antibiotic resistance of methicillin-resistant Staphylococcus aureus isolated from hospital food. Antimicrob Resist Infect Control. 2017;6(1):104.

67. Braide W, Oranusi S, Nwaoguikpe R, Offor-Emenike I, Nwosu I, Akobondu C, Chike-Reginald C, Popgbara L. Evaluation of the microbiological status and antibacterial susceptibility pattern of some herbal remedies administered orally in Nigeria. Research J Engin App Sci. 2013;2(1):35-42.

68. Ngemenya MN, Djeukem GGR, Nyongbela KD, Bate PNN, Babiaka SB, Monya E, Kanso RK. Microbial, phytochemical, toxicity analyses and antibacterial activity against multidrug resistant bacteria of some traditional remedies sold in Buea Southwest Cameroon. BMC Complement Alternat Med. 2019;19(1):150.

69. Momtaz H, Dehkordi FS, Rahimi E, Asgarifar A, Momeni M. Virulence genes and antimicrobial resistance profiles of Staphylococcus aureus isolated from chicken meat in Isfahan province, Iran. J App Poultry Res. 2013;22(4):913-921.

70. Paludi D, Vergara A, Festino AR, Di Ciccio P, Costanzo C, Conter M, Zanardi E, Ghidini S, lanieri A. Antimicrobial resistance pattern of methicillin-resistant Staphylococcus aureus in the food industry. J Biol Regulat Homeostatic Agents. 2011;25(4):671.

71. Sallam Kl, Abd-Elghany SM, Elhadidy M, Tamura T. Molecular characterization and antimicrobial resistance profile of methicillin-resistant Staphylococcus aureus in retail chicken. J Food Protect. 2015;78(10):1879-1884.

72. Jackson CR, Davis JA, Barrett JB. Prevalence and characterization of methicillin-resistant Staphylococcus aureus isolates from retail meat and humans in Georgia. J Clin Microbiol. 2013;51(4):1199-1207.

73. Daka D, Yihdego D. Antibiotic-resistance Staphylococcus aureus isolated from cow's milk in the Hawassa area, South Ethiopia. Ann Clin Microbiol Antimicrob. 2012;11(1):26.

74. Hasanpour Dehkordi A, Khaji L, Sakhaei Shahreza M, Mashak Z, Safarpoor Dehkordi F, Safaee Y, Hosseinzadeh A, Alavi I, Ghasemi E, Rabiei-Faradonbeh M. One-year prevalence of antimicrobial susceptibility pattern of methicillin-resistant Staphylococcus aureus recovered from raw meat. Trop Biomed. 2017;34(2):396-404.

75. Safarpoor Dehkordi F, Basti AA, Gandomi H, Misaghi A, Rahimi E. Retracted: Pathogenic Staphylococcus aureus in hospital food samples; prevalence and antimicrobial resistance properties. J Food Safety. 2018;38(6):e12501.

76. Rahi A, Kazemeini H, Jafariaskari S, Seif A, Hosseini S, Dehkordi FS. Genotypic and Phenotypic-Based Assessment of Antibiotic Resistance and Profile of Staphylococcal Cassette Chromosome mec in the Methicillin-Resistant Staphylococcus aureus Recovered from Raw Milk. Infect Drug Resist. $2020 ; 13273$.

77. Wang Y-T, Lin Y-T, Wan T-W, Wang D-Y, Lin H-Y, Lin C-Y, Chen Y-C, Teng L-J. Distribution of antibiotic resistance genes among Staphylococcus species isolated from ready-to-eat foods. J Food Drug Analysis. 2019;27(4):841-848.

78. Abdolmaleki Z, Mashak Z, Dehkordi FS. Phenotypic and genotypic characterization of antibiotic resistance in the methicillin-resistant Staphylococcus aureus strains isolated from hospital cockroaches. Antimicrob Resist Infect Control. 2019;8(1):54.

79. Zehra A, Singh R, Kaur S, Gill J. Molecular characterization of antibiotic-resistant Staphylococcus aureus from livestock (bovine and swine). Vet World. 2017;10(6):598.

80. Ugwu CC, Gomez-Sanz E, Agbo IC, Torres C, Chah KF. Characterization of mannitol-fermenting methicillin-resistant staphylococci isolated from pigs in Nigeria. Brazilian J Microbiol. 2015;46(3):885-892.

81. Johler S, Layer F, Stephan R. Comparison of virulence and antibiotic resistance genes of food poisoning outbreak isolates of Staphylococcus aureus with isolates obtained from bovine mastitis milk and pig carcasses. J Food Protect. 2011;74(11):1852-1859.

82. Osman K, Badr J, Al-Maary KS, Moussa IM, Hessain AM, Girah Z, Amin M, Abo-shama UH, Orabi A, Saad A. Prevalence of the antibiotic resistance genes in coagulase-positive-and negative-Staphylococcus in chicken meat retailed to consumers. Front Microbiol. 2016;71846.

83. Merz A, Stephan R, Johler S. Staphylococcus aureus isolates from goat and sheep milk seem to be closely related and differ from isolates detected from bovine milk. Front Microbiol. 2016;7319.

84. Ranjbar R, Shahreza MHS, Rahimi E, Jonaidi-Jafari N. Methicillin-resistant Staphylococcus aureus isolates from Iranian restaurant food samples: PantonValentine Leukocidin, SCCmec phenotypes and antimicrobial resistance. Tropical J Pharma Res. 2017;16(8):1939-1949.

85. Hizlisoy H, ONMAZ NE, Karadal F, Serhat A, Yildirim Y, Gonulalan Z, Kilic H. Antibiotic Resistance Gene Profiles of Staphylococcus aureus Isolated From Foods of Animal Origin. Kafkas Üni Vet Fakült Derg. 2018;24(2).

86. Wu S, Huang J, Zhang F, Wu Q, Zhang J, Pang R, Zeng H, Yang X, Chen M, Wang J. Prevalence and characterization of food-related methicillin-resistant Staphylococcus aureus (MRSA) in China. Front Microbiol. 2019;10304.

87. Waters AE, Contente-Cuomo T, Buchhagen J, Liu CM, Watson L, Pearce K, Foster JT, Bowers J, Driebe EM, Engelthaler DM. Multidrug-resistant Staphylococcus aureus in US meat and poultry. Clin Infectious Dis. 2011;52(10):1227-1230.

Page $9 / 17$ 
88. Alfouzan W, Udo EE, Modhaffer A. Molecular Characterization of Methicillin-Resistant Staphylococcus aureus in a Tertiary Care hospital in Kuwait. Scientific Reports. 2019;9(1):1-8.

89. Mohammed J, Ziwa MH, Hounmanou YMG, Kisanga A, Tuntufye HN. Molecular typing and antimicrobial susceptibility of methicillin-resistant Staphylococcus aureus isolated from bovine milk in Tanzania. Int J Microbiol. 2018;2018.

\section{Tables}

Table 1. PCR conditions to amplify antibiotic resistance genes amongst the $S$. aureus bacteria isolated from powdered packaged medicinal plants and bottle herbal distillate samples. 


\begin{tabular}{|c|c|c|c|c|c|}
\hline $\begin{array}{l}\text { Target } \\
\text { gene }\end{array}$ & $\begin{array}{l}\text { Encoding } \\
\text { antibiotic }\end{array}$ & Primer sequence (5'-3') & $\begin{array}{l}\text { PCR } \\
\text { product } \\
\text { (bp) }\end{array}$ & $\begin{array}{l}\text { PCR } \\
\text { programs }\end{array}$ & PCR volume $(50 \mu \mathrm{L})$ \\
\hline \multirow[t]{2}{*}{$a a c A-D$} & \multirow[t]{2}{*}{ Aminoglycosides } & F: TAATCCAAGAGCAATAAGGGC & \multirow[t]{2}{*}{227} & 1 cycle: & $5 \mu \mathrm{L}$ PCR buffer $10 \mathrm{X}$ \\
\hline & & R: GCCACACTATCATAACCACTA & & $94^{\circ \mathrm{C}}$ & $1.5 \mathrm{mM} \mathrm{MgCl}_{2}$ \\
\hline \multirow[t]{2}{*}{ ermA } & \multirow[t]{2}{*}{ Macrolides } & F: AAGCGGTAAACCCCTCTGA & \multirow[t]{2}{*}{190} & $250 y+8$ & $200 \mu \mathrm{M}$ dNTP (Thermo Fisher Scientific, St. \\
\hline & & R: TTCGCAAATCCCTTCTCAAC & & 20, & 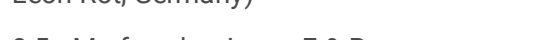 \\
\hline \multirow[t]{2}{*}{ tetK } & \multirow[t]{2}{*}{ Tetracyclines } & F: GTAGCGACAATAGGTAATAGT & \multirow[t]{2}{*}{360} & $\begin{array}{l}94^{0 C} \\
-60 s\end{array}$ & $0.5 \mu \mathrm{M}$ of each primers $\mathrm{F} \& \mathrm{R}$ \\
\hline & & R: GTAGTGACAATAAACCTCCTA & & $55^{0 \mathrm{CC}}$ & Scientific, St. Leon-Rot, Germany) \\
\hline \multirow[t]{2}{*}{ ermB } & \multirow[t]{2}{*}{ Macrolides } & $\begin{array}{l}\text { F: } \\
\text { CCGTTTACGAAATTGGAACAGGTAAAGGGC }\end{array}$ & \multirow[t]{2}{*}{359} & $720 \mathrm{C}$ & $2.5 \mu \mathrm{L}$ DNA template \\
\hline & & R: GAATCGAGACTTGAGTGTGC & & $-60 s$ & \\
\hline \multirow[t]{2}{*}{$g r / A$} & \multirow[t]{2}{*}{ Fluoroquinolones } & F: ACTTGAAGATGTTTTAGGTGAT & \multirow[t]{2}{*}{618} & There. & \\
\hline & & R: TTAGGAAATCTTGATGGCAA & & $\frac{72^{0 \mathrm{C}}}{-10 \mathrm{~min}}$ & \\
\hline \multirow[t]{6}{*}{ tetM } & \multirow[t]{6}{*}{ Tetracyclines } & F: AGTGGAGCGATTACAGAA & \multirow[t]{6}{*}{158} & 1 cycle: & $5 \mu \mathrm{L}$ PCR buffer $10 \mathrm{X}$ \\
\hline & & R: CATATGTCCTGGCGTGTCTA & & $\begin{array}{l}94^{\circ \mathrm{CC}} \\
-6 \mathrm{~min} .\end{array}$ & $2 \mathrm{mM} \mathrm{MgCl}_{2}$ \\
\hline & & & & 34 cycles: & $200 \mu \mathrm{M}$ dNTP \\
\hline & & & & $95^{00}$ & $0.5 \mu \mathrm{M}$ of each primers $\mathrm{F} \& \mathrm{R}$ \\
\hline & & & & $-50 \mathrm{~s}$ & 1.5 U Taq DNA polymerase \\
\hline & & & & $55^{\circ \mathrm{CC}}$ & $5 \mu \mathrm{L}$ DNA template \\
\hline \multirow[t]{4}{*}{ gyrA } & \multirow[t]{4}{*}{ Fluoroquinolones } & F: AGTACATCGTCGTATACTATATGG & \multirow[t]{4}{*}{280} & $-70 s$ & \\
\hline & & R: ATCACGTAACAGTTCAAGTGTG & & $\begin{array}{l}72^{\circ \mathrm{C}} \\
-60 \mathrm{~s}\end{array}$ & \\
\hline & & & & 1 cycle: & \\
\hline & & & & $\begin{array}{l}72^{\circ \mathrm{C}} \\
-8 \mathrm{~min}\end{array}$ & \\
\hline \multirow[t]{3}{*}{$m s r A$} & \multirow[t]{3}{*}{ Macrolides } & F: GGCACAATAAGAGTGTTTAAAGG & \multirow[t]{3}{*}{940} & 1 cycle: & $5 \mu \mathrm{L}$ PCR buffer $10 \mathrm{X}$ \\
\hline & & R: AAGTTATATCATGAATAGATTGTCCTGTT & & $\begin{array}{l}94^{\circ \mathrm{CC}} \\
-6 \mathrm{~min} .\end{array}$ & $2 \mathrm{mM} \mathrm{MgCl}_{2}$ \\
\hline & & & & 34 cycles: & $150 \mu \mathrm{M} d N T P$ \\
\hline \multirow[t]{3}{*}{$m s r B$} & \multirow[t]{3}{*}{ Macrolides } & F: TATGATATCCATAATAATTATCCAATC & \multirow[t]{3}{*}{595} & $\begin{array}{l}95^{\circ \mathrm{C}} \\
-60 \mathrm{~s}\end{array}$ & $\begin{array}{l}0.15 \mu \mathrm{M} \text { of each primers } \mathrm{F} \& \mathrm{R} \\
1.5 \mathrm{U} \text { Taq DNA polymerase }\end{array}$ \\
\hline & & R: AAGTTATATCATGAATAGATTGTCCTGTT & & $\begin{array}{l}50 \mathrm{oc} \\
-70 \mathrm{~s}\end{array}$ & $3 \mu \mathrm{L}$ DNA template \\
\hline & & & & $\frac{72^{\circ 0 \mathrm{C}}}{-70 \mathrm{~s}}$ & \\
\hline \multirow[t]{2}{*}{ dfra1 } & \multirow{2}{*}{$\begin{array}{l}\text { Folate pathway } \\
\text { antagonists }\end{array}$} & F: CTCACGATAAACAAAGAGTCA & 201 & 1 cycle: & \\
\hline & & R: CAATCATTGCTTCGTATAACG & & $\begin{array}{l}72^{\circ \mathrm{C}} \\
-8 \mathrm{~min}\end{array}$ & \\
\hline $\operatorname{lin} A$ & Lincosamides & $\begin{array}{l}\text { F: } \\
\text { GGTGGCTGGGGGGTAGATGTATTAACTGG }\end{array}$ & 323 & 1 cycle: & $5 \mu \mathrm{L}$ PCR buffer $10 \mathrm{X}$ \\
\hline & & R: & & $\begin{array}{l}94^{\circ \mathrm{C}} \\
-6 \mathrm{~min} .\end{array}$ & $2 \mathrm{mM} \mathrm{MgCl}_{2}$ \\
\hline & & & & 30 cycles: & $150 \mu \mathrm{M}$ dNTP \\
\hline & & & & $\begin{array}{l}95^{0 \mathrm{C}} \\
-60 \mathrm{~s}\end{array}$ & $\begin{array}{l}0.75 \mu \mathrm{M} \text { of each primers } \mathrm{F} \& \mathrm{R} \\
1.5 \mathrm{U} \text { Taq DNA polymerase }\end{array}$ \\
\hline & & & & $\begin{array}{l}57^{\circ 0 \mathrm{C}} \\
-60 \mathrm{~s}\end{array}$ & $3 \mu \mathrm{L}$ DNA template \\
\hline
\end{tabular}


1 cycle:

$72^{0 \mathrm{C}}$

$-10 \mathrm{~min}$

\begin{tabular}{|c|c|c|c|c|c|}
\hline \multirow{9}{*}{ rpoB } & \multirow{9}{*}{ Ansamycins } & F: ACCGTCGTTTACGTTCTGTA & \multirow[t]{9}{*}{460} & 1 cycle: & $5 \mu \mathrm{L}$ PCR buffer $10 \mathrm{X}$ \\
\hline & & \multirow[t]{8}{*}{ R: TCAGTGATAGCATGTGTATC } & & $94^{\circ \mathrm{CC}}$ & $2 \mathrm{mM} \mathrm{MgCl} 2$ \\
\hline & & & & & $150 \mu \mathrm{M} d \mathrm{dNTP}$ \\
\hline & & & & 40 cycies. & $0.75 \mu \mathrm{M}$ of each primers $\mathrm{F} \& \mathrm{R}$ \\
\hline & & & & $\begin{array}{l}940 \mathrm{CO} \\
-40 \mathrm{~s}\end{array}$ & 1.5 U Taq DNA polymerase \\
\hline & & & & $\frac{45.5^{0 \mathrm{C}}}{-40 \mathrm{~s}}$ & $3 \mu \mathrm{L}$ DNA template \\
\hline & & & & $\begin{array}{l}72^{\circ \mathrm{C}} \\
-90 \mathrm{~s}\end{array}$ & \\
\hline & & & & 1 cycle: & \\
\hline & & & & $\begin{array}{l}72^{\circ \mathrm{C}} \\
-8 \mathrm{~min}\end{array}$ & \\
\hline
\end{tabular}

blaz Penicillins

F: TGAACCGTATGTTAGTGC

681

1 cycle:

$5 \mu \mathrm{L}$ PCR buffer $10 \mathrm{X}$

R: GTCGTGTTAGCGTTGATA

$94^{\circ \mathrm{C}}$

$-6 \mathrm{~min}$.

$2 \mathrm{mM} \mathrm{MgCl}_{2}$

30 cycles:

$150 \mu \mathrm{M}$ dNTP

$95^{0 \mathrm{C}}$

$-60 s$

$0.75 \mu \mathrm{M}$ of each primers $\mathrm{F} \& \mathrm{R}$

$590 \mathrm{C}$

1.5 U Taq DNA polymerase

$-60 \mathrm{~s}$

$72^{\circ \mathrm{CC}}$

$-60 s$

1 cycle:

$72^{0 \mathrm{c}}$

$-10 \mathrm{~min}$

\begin{tabular}{|c|c|c|c|c|c|}
\hline \multirow[t]{8}{*}{ fexA } & \multirow[t]{8}{*}{ Phenicols } & F: GTACTTGTAGGTGCAATTACGGCTGA & \multirow[t]{8}{*}{1272} & 1 cycle: & $5 \mu \mathrm{L}$ PCR buffer $10 \mathrm{X}$ \\
\hline & & \multirow[t]{7}{*}{ R: CGCATCTGAGTAGGACATAGCGTC } & & $\begin{array}{l}94^{\mathrm{OC}} \\
-1 \mathrm{~min} .\end{array}$ & $2 \mathrm{mM} \mathrm{MgCl}_{2}$ \\
\hline & & & & 34 cycles: & 150 HM dNIP \\
\hline & & & & $\begin{array}{l}94^{0 \mathrm{C}} \\
-1 \mathrm{~min}\end{array}$ & 1.5 U Taq DNA polymerase \\
\hline & & & & $\begin{array}{l}57^{\circ \mathrm{C}} \\
-2 \mathrm{~min}\end{array}$ & $3 \mu \mathrm{L}$ DNA template \\
\hline & & & & $\begin{array}{l}72^{\circ \mathrm{C}} \\
-3 \mathrm{~min}\end{array}$ & \\
\hline & & & & 1 cycle: & \\
\hline & & & & $72^{\mathrm{OC}}$ & \\
\hline
\end{tabular}




\begin{tabular}{|c|c|c|c|c|c|}
\hline & & & & $\begin{array}{l}98 \text { oc } \\
-10 \mathrm{~s} \\
50 \text { oc } \\
-60 \mathrm{~s} \\
720 \mathrm{c} \\
-90 \mathrm{~s} \\
1 \text { cycle: } \\
72 \text { oc } \\
-10 \mathrm{~min}\end{array}$ & $\begin{array}{l}0.75 \mu \mathrm{M} \text { of each primers } \mathrm{F} \& \mathrm{R} \\
1.5 \mathrm{U} \text { Taq DNA polymerase } \\
3 \mu \mathrm{L} \text { DNA template }\end{array}$ \\
\hline $\operatorname{van} B$ & Glycopeptides & $\begin{array}{l}\text { F: GTGACAAACCGGAGGCGAGGA } \\
\text { R: CCGCCATCCTCCTGCAAAAAA }\end{array}$ & 430 & $\begin{array}{l}1 \text { cycle: } \\
94 \text { oc } \\
-10 \mathrm{~min} . \\
30 \text { cycles: } \\
94^{\circ \mathrm{CC}} \\
-30 \mathrm{~s} \\
50 \text { oc } \\
-45 \mathrm{~s} \\
720 \mathrm{c} \\
-30 \mathrm{~s} \\
1 \mathrm{cycle}: \\
72 \text { oc } \\
-10 \mathrm{~min}\end{array}$ & $\begin{array}{l}5 \mu \mathrm{L} \text { PCR buffer } 10 \mathrm{X} \\
2 \mathrm{mM} \mathrm{MgCl} \\
150 \mu \mathrm{M} \text { dNTP } \\
0.75 \mu \mathrm{M} \text { of each primers } \mathrm{F} \& \mathrm{R} \\
1.5 \mathrm{U} \text { Taq DNA polymerase } \\
3 \mu \mathrm{L} \text { DNA template }\end{array}$ \\
\hline $\operatorname{mec} A$ & Penicillins & $\begin{array}{l}\text { F: AAAATCGATGGTAAAGGTTGGC } \\
\text { R: AGTTCTGCAGTACCGGATTTGC }\end{array}$ & 532 & 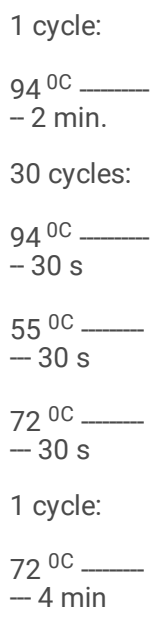 & $\begin{array}{l}5 \mu \mathrm{L} \text { PCR buffer } 10 \mathrm{X} \\
2 \mathrm{mM} \mathrm{MgCl} \\
150 \mu \mathrm{M} \text { dNTP } \\
0.75 \mu \mathrm{M} \text { of each primers } \mathrm{F} \& \mathrm{R} \\
1.5 \mathrm{U} \text { Taq DNA polymerase } \\
3 \mu \mathrm{L} \text { DNA template }\end{array}$ \\
\hline vatA & Streptogramins & $\begin{array}{l}\text { F: TGGTCCCGGAACAACATTTAT } \\
\text { R: TCCACCGACAATAGAATAGGG }\end{array}$ & 268 & 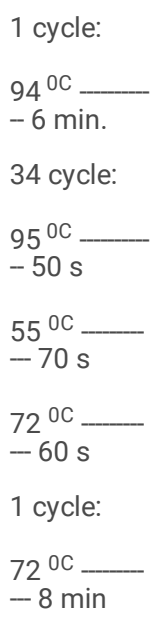 & $\begin{array}{l}5 \mu \mathrm{L} \text { PCR buffer } 10 \mathrm{X} \\
2 \mathrm{mM} \mathrm{Mgcl}{ }_{2} \\
200 \mu \mathrm{M} \text { dNTP } \\
0.5 \mu \mathrm{M} \text { of each primers } \\
1.5 \mathrm{U} \text { Taq DNA polymerase } \\
5 \mu \mathrm{L} \text { DNA template }\end{array}$ \\
\hline vatB & Streptogramins & $\begin{array}{l}\text { F: GCTGCGAATTCAGTTGTTACA } \\
\text { R: CTGACCAATCCCACCATTTTA }\end{array}$ & 136 & 1 cycle: & $\begin{array}{l}5 \mu \mathrm{L} \text { PCR buffer } 10 \mathrm{X} \\
2 \mathrm{mM} \mathrm{Mgcl}_{2}\end{array}$ \\
\hline
\end{tabular}




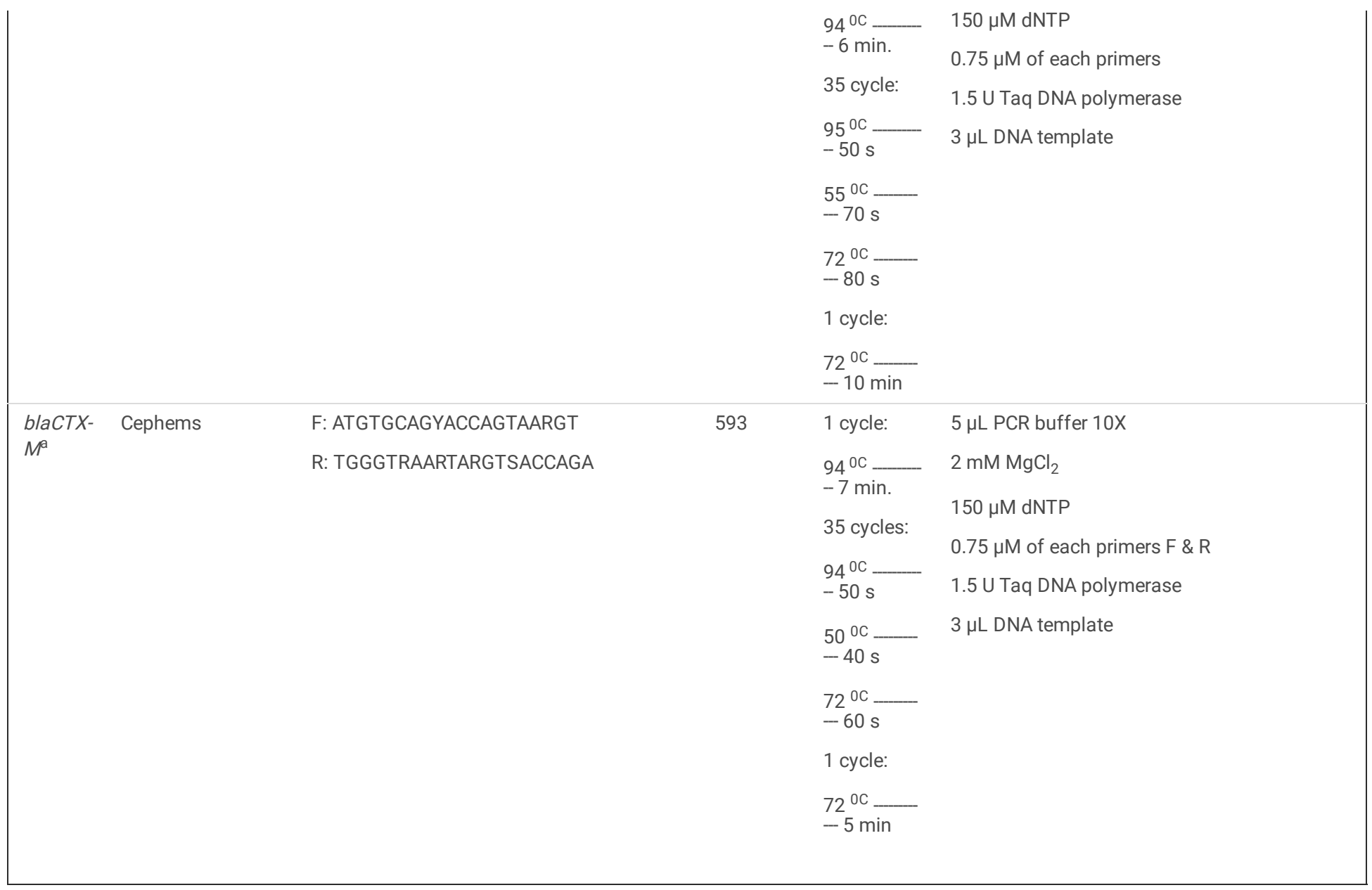

${ }^{\mathrm{a}} \mathrm{R}$ is $\mathrm{A}$ or $\mathrm{G} ; \mathrm{Y}$ is $\mathrm{C}$ or $\mathrm{T}$; $\mathrm{S}$ is $\mathrm{G}$ or $\mathrm{C}$.

Table 2. Contamination rate of diverse kinds of powdered packaged medicinal plants and bottle herbal distillate samples with the $S$. aureus.

\begin{tabular}{|llll|}
\hline Types of samples & & N. samples collected & N. samples contaminated with S. aureus (\%) \\
\hline \multirow{5}{*}{ Medicinal plants } & Z. multiflora & 30 & $2(6.66)$ \\
\cline { 2 - 4 } & S. bachtiarica & 30 & $2(6.66)$ \\
\cline { 2 - 4 } Herbal Distillates & A. citrodora & 30 & $3(10)$ \\
\cline { 2 - 4 } & R. damascene & 30 & $3(10)$ \\
\cline { 2 - 4 } & Total & 120 & $10(8.33)$ \\
& L. angustifolia & 30 & $4(13.33)$ \\
\cline { 2 - 4 } & A. maurorum & 30 & $5(16.66)$ \\
& C. intybus & 30 & $3(10)$ \\
& M. officinalis & 30 & $2(6.66)$ \\
\cline { 2 - 4 } & M. piperita & 30 & $2(6.66)$ \\
\hline Total & F. officinalis & 30 & $4(13.33)$ \\
& Total & 180 & $\mathbf{2 0}(11.11)$ \\
\hline
\end{tabular}

Table 3. The phenotypic pattem of antibiotic resistance of $S$. aureus bacteria isolated from diverse powdered packaged medicinal plants and bottle herbal distillate samples. 


\begin{tabular}{|c|c|c|c|c|c|c|c|c|c|c|c|c|}
\hline \multirow{2}{*}{\multicolumn{2}{|c|}{$\begin{array}{l}\text { Types of samples (N. S. } \\
\text { aureus) }\end{array}$}} & \multicolumn{11}{|c|}{ N. S. aureus isolates resist to each antibiotic agent (\%) } \\
\hline & & \multicolumn{2}{|c|}{ Penicillins } & \multicolumn{2}{|c|}{ Cephems } & \multirow{2}{*}{$\begin{array}{l}\text { Glycopeptides } \\
\text { Van }\end{array}$} & \multirow{2}{*}{$\begin{array}{l}\text { Aminoglycosides } \\
\text { Gen }\end{array}$} & \multicolumn{2}{|c|}{ Macrolides } & \multicolumn{2}{|c|}{ Tetracyclines } & \multirow{2}{*}{$\begin{array}{l}\text { Flur } \\
\text { Cip }\end{array}$} \\
\hline & & Ox & $\mathrm{P} 10$ & $C f x$ & $\mathrm{Cft}$ & & & $A z$ & Ert & Tet & Dox & \\
\hline \multirow[t]{5}{*}{$\begin{array}{l}\text { Medicinal } \\
\text { plants }\end{array}$} & $\begin{array}{l}Z \text {. } \\
\text { multiflora } \\
(2)\end{array}$ & $1(50)$ & $2(100)$ & $1(50)$ & $1(50)$ & - & $2(100)$ & $1(50)$ & $1(50)$ & $2(100)$ & $1(50)$ & $1(5$ \\
\hline & $\begin{array}{l}S . \\
\text { bachtiarica } \\
(2)\end{array}$ & $1(50)$ & $2(100)$ & $1(50)$ & $1(50)$ & $1(50)$ & $1(50)$ & $1(50)$ & $1(50)$ & $2(100)$ & $1(50)$ & $1(5$ \\
\hline & $\begin{array}{l}\text { A. citrodora } \\
\text { (3) }\end{array}$ & $\begin{array}{l}1 \\
(33.33)\end{array}$ & $\begin{array}{l}2 \\
(66.66)\end{array}$ & $\begin{array}{l}1 \\
(33.33)\end{array}$ & $\begin{array}{l}1 \\
(33.33)\end{array}$ & $1(33.33)$ & $2(66.66)$ & $\begin{array}{l}1 \\
(33.33)\end{array}$ & $\begin{array}{l}2 \\
(66.66)\end{array}$ & $\begin{array}{l}2 \\
(66.66)\end{array}$ & $\begin{array}{l}1 \\
(33.33)\end{array}$ & $\begin{array}{l}1 \\
(33 .\end{array}$ \\
\hline & $\begin{array}{l}R \text {. } \\
\text { damascene } \\
\text { (3) }\end{array}$ & $\begin{array}{l}1 \\
(33.33)\end{array}$ & $3(100)$ & $\begin{array}{l}1 \\
(33.33)\end{array}$ & $\begin{array}{l}1 \\
(33.33)\end{array}$ & 1 (33.33) & $2(66.66)$ & $\begin{array}{l}1 \\
(33.33)\end{array}$ & $\begin{array}{l}2 \\
(66.66)\end{array}$ & $\begin{array}{l}2 \\
(66.66)\end{array}$ & $\begin{array}{l}1 \\
(33.33)\end{array}$ & $\begin{array}{l}1 \\
(33 .:\end{array}$ \\
\hline & Total (10) & $4(40)$ & $9(90)$ & $4(40)$ & $4(40)$ & $3(30)$ & $7(70)$ & $4(40)$ & $6(60)$ & $8(80)$ & $4(40)$ & $4(4$ \\
\hline \multirow[t]{7}{*}{$\begin{array}{l}\text { Herbal } \\
\text { Distillates }\end{array}$} & $\begin{array}{l}\text { L. } \\
\text { angustifolia } \\
(4)\end{array}$ & $2(50)$ & $4(100)$ & $2(50)$ & $2(50)$ & $1(25)$ & $3(75)$ & $2(50)$ & $3(75)$ & $4(100)$ & $2(50)$ & $2(5$ \\
\hline & $\begin{array}{l}\text { A. } \\
\text { maurorum } \\
\text { (5) }\end{array}$ & $2(40)$ & $4(80)$ & $3(60)$ & $3(60)$ & $2(40)$ & $5(100)$ & $2(40)$ & $4(80)$ & $5(100)$ & $2(40)$ & $3(6)$ \\
\hline & $\begin{array}{l}\text { C. intybus } \\
\text { (3) }\end{array}$ & $\begin{array}{l}2 \\
(66.66)\end{array}$ & $3(100)$ & $\begin{array}{l}2 \\
(66.66)\end{array}$ & $\begin{array}{l}1 \\
(33.33)\end{array}$ & 1 (33.33) & $3(100)$ & $\begin{array}{l}1 \\
(33.33)\end{array}$ & $\begin{array}{l}2 \\
(66.66)\end{array}$ & $\begin{array}{l}2 \\
(66.66)\end{array}$ & $\begin{array}{l}1 \\
(33.33)\end{array}$ & $\begin{array}{l}2 \\
(66 .\end{array}$ \\
\hline & $\begin{array}{l}\text { M. } \\
\text { officinalis } \\
\text { (2) }\end{array}$ & $2(100)$ & $2(100)$ & $1(50)$ & $1(50)$ & $1(50)$ & $2(100)$ & $1(50)$ & $2(100)$ & $2(100)$ & $1(50)$ & $1(5$ \\
\hline & $\underset{(2)}{\text { M. piperita }}$ & $1(50)$ & $2(100)$ & $1(50)$ & $1(50)$ & $1(50)$ & $2(100)$ & $1(50)$ & $1(50)$ & $2(100)$ & $1(50)$ & $1(5$ \\
\hline & $\begin{array}{l}\text { F. officinalis } \\
\text { (4) }\end{array}$ & $2(50)$ & $4(100)$ & $2(50)$ & $2(50)$ & $1(25)$ & $4(100)$ & $2(50)$ & $3(75)$ & $4(100)$ & $2(50)$ & $3(7$ \\
\hline & Total (20) & $11(55)$ & 19 (95) & $11(55)$ & $10(50)$ & $9(45)$ & $19(95)$ & $9(45)$ & $15(75)$ & 19 (95) & $9(45)$ & 12( \\
\hline Total (30) & & $15(50)$ & $\begin{array}{l}28 \\
(93.33)\end{array}$ & $15(50)$ & $\begin{array}{l}14 \\
(46.66)\end{array}$ & $12(40)$ & $26(86.66)$ & $\begin{array}{l}13 \\
\text { (43.33) }\end{array}$ & $21(70)$ & $27(90)$ & $\begin{array}{l}13 \\
(43.33)\end{array}$ & $\begin{array}{l}16 \\
(53 .\end{array}$ \\
\hline
\end{tabular}

*Ox: oxacillin (1 $\mu \mathrm{g} /$ disk), P10: penicillin (10 units/disk), Cfx: cefoxitin (30 $\mu \mathrm{g} / \mathrm{disk})$, Cft: ceftaroline (30 $\mu \mathrm{g} / \mathrm{disk})$, Van: vancomycin (5 $\mu \mathrm{g} / \mathrm{disk}))$, Gen:

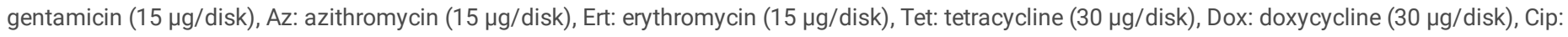
ciprofloxacin $(5 \mu \mathrm{g} / \mathrm{disk})$, Lev: levofloxacin $(5 \mu \mathrm{g} / \mathrm{disk})$, Nit: nitrofurantoin (300 $\mu \mathrm{g} / \mathrm{disk})$, Cln: clindamycin (2 $\mu \mathrm{g} /$ disk), Trs: trimethoprim-sulfamethoxazole (1.25/23.75 $\mu \mathrm{g} /$ disk), C30: chloramphenicol (30 $\mu \mathrm{g} /$ disk), Rif: rifampin (5 $\mu \mathrm{g} /$ disk), Qd: quinupristin-dalfopristin (15 $\mu \mathrm{g} / \mathrm{disk})$.

Table 4. The genotypic pattern of antibiotic resistance of $S$. aureus bacteria isolated from diverse kinds of powdered packaged medicinal plants and bottle herbal distillate samples 


\begin{tabular}{|c|c|c|c|c|c|c|c|c|c|c|c|c|}
\hline \multirow{2}{*}{\multicolumn{2}{|c|}{$\begin{array}{l}\text { Types of samples (N. S. } \\
\text { aureus) }\end{array}$}} & \multicolumn{11}{|c|}{ N. S. aureus isolates resist to each antibiotic agent (\%) } \\
\hline & & \multicolumn{2}{|c|}{ Penicillins } & \multirow{2}{*}{$\begin{array}{l}\text { Cephems } \\
\text { blaCTX- } \\
M\end{array}$} & \multicolumn{2}{|c|}{ Glycopeptides } & \multirow{2}{*}{$\begin{array}{l}\text { Aminoglycosides } \\
\text { aacA-D }\end{array}$} & \multicolumn{4}{|c|}{ Macrolides } & \multirow{2}{*}{$\begin{array}{l}\text { Tetracycl } \\
\text { tetK }\end{array}$} \\
\hline & & $\operatorname{Mec} A$ & blaz & & $\operatorname{van} A$ & $\operatorname{van} B$ & & ermA & ermB & $m s r A$ & $m s r B$ & \\
\hline \multirow[t]{5}{*}{$\begin{array}{l}\text { Medicinal } \\
\text { plants }\end{array}$} & $\begin{array}{l}\text { Z. } \\
\text { multiflora } \\
(2)\end{array}$ & $1(50)$ & $1(50)$ & $1(50)$ & - & - & $1(50)$ & $1(50)$ & - & $1(50)$ & - & $1(50)$ \\
\hline & $\begin{array}{l}S . \\
\text { bachtiarica } \\
(2)\end{array}$ & $1(50)$ & $1(50)$ & $1(50)$ & $1(50)$ & - & $1(50)$ & $1(50)$ & - & $1(50)$ & - & $1(50)$ \\
\hline & $\begin{array}{l}\text { A. citrodora } \\
\text { (3) }\end{array}$ & $\begin{array}{l}1 \\
(33.33)\end{array}$ & $\begin{array}{l}2 \\
(66.66)\end{array}$ & 1 (33.33) & $\begin{array}{l}1 \\
(33.33)\end{array}$ & - & 1 (33.33) & $\begin{array}{l}1 \\
(33.33)\end{array}$ & $\begin{array}{l}1 \\
(33.33)\end{array}$ & $\begin{array}{l}1 \\
(33.33)\end{array}$ & - & $\begin{array}{l}2 \\
(66.66)\end{array}$ \\
\hline & $\begin{array}{l}R \text {. } \\
\text { damascene } \\
(3)\end{array}$ & $\begin{array}{l}1 \\
(33.33)\end{array}$ & $\begin{array}{l}2 \\
(66.66)\end{array}$ & $1(33.33)$ & - & $\begin{array}{l}1 \\
(33.33)\end{array}$ & $1(33.33)$ & $\begin{array}{l}1 \\
(33.33)\end{array}$ & - & $\begin{array}{l}1 \\
(33.33)\end{array}$ & $\begin{array}{l}1 \\
(33.33)\end{array}$ & $\begin{array}{l}2 \\
(66.66)\end{array}$ \\
\hline & Total (10) & $4(40)$ & $6(60)$ & $4(40)$ & $2(20)$ & $1(10)$ & $4(40)$ & $4(40)$ & $1(10)$ & $4(40)$ & $1(10)$ & $6(60)$ \\
\hline \multirow[t]{7}{*}{$\begin{array}{l}\text { Herbal } \\
\text { Distillates }\end{array}$} & $\begin{array}{l}\text { L. } \\
\text { angustifolia } \\
(4)\end{array}$ & $2(50)$ & $3(75)$ & $1(25)$ & $1(25)$ & $1(25)$ & $2(50)$ & $2(50)$ & - & $2(50)$ & - & $3(75)$ \\
\hline & $\begin{array}{l}\text { A. } \\
\text { maurorum } \\
(5)\end{array}$ & $2(40)$ & $3(60)$ & $2(40)$ & $2(40)$ & $1(20)$ & $2(40)$ & $2(40)$ & $1(20)$ & $2(40)$ & - & $3(60)$ \\
\hline & $\begin{array}{l}\text { C. intybus } \\
\text { (3) }\end{array}$ & $\begin{array}{l}1 \\
(33.33)\end{array}$ & $\begin{array}{l}2 \\
(66.66)\end{array}$ & 1 (33.33) & $\begin{array}{l}1 \\
(33.33)\end{array}$ & - & 1 (33.33) & $\begin{array}{l}2 \\
(66.66)\end{array}$ & $\begin{array}{l}1 \\
(33.33)\end{array}$ & $\begin{array}{l}1 \\
(33.33)\end{array}$ & - & $\begin{array}{l}2 \\
(66.66)\end{array}$ \\
\hline & $\begin{array}{l}\text { M. } \\
\text { officinalis } \\
(2)\end{array}$ & $1(50)$ & $1(50)$ & $1(50)$ & $1(50)$ & - & $1(50)$ & $1(50)$ & - & $1(50)$ & $1(50)$ & $1(50)$ \\
\hline & $\underset{(2)}{M_{\text {. }} \text { piperita }}$ & $1(50)$ & $1(50)$ & $1(50)$ & - & - & $1(50)$ & $1(50)$ & - & $1(50)$ & - & $1(50)$ \\
\hline & $\begin{array}{l}\text { F. officinalis } \\
\text { (4) }\end{array}$ & $2(50)$ & $3(75)$ & $1(25)$ & $1(25)$ & $1(25)$ & $2(50)$ & $2(50)$ & - & $2(50)$ & - & $2(50)$ \\
\hline & Total (20) & $9(45)$ & $13(65)$ & $7(35)$ & $6(30)$ & $3(15)$ & $9(45)$ & $10(50)$ & $2(10)$ & $9(45)$ & $1(5)$ & $12(60)$ \\
\hline Total (30) & & $\begin{array}{l}13 \\
\text { (43.33) }\end{array}$ & $\begin{array}{l}19 \\
(63.33)\end{array}$ & $\begin{array}{l}11 \\
(36.66)\end{array}$ & $\begin{array}{l}8 \\
(26.66)\end{array}$ & $\begin{array}{l}4 \\
(13.33)\end{array}$ & 13 (43.33) & $\begin{array}{l}14 \\
(46.66)\end{array}$ & $3(10)$ & $\begin{array}{l}13 \\
(43.33)\end{array}$ & $\begin{array}{l}2 \\
(6.66)\end{array}$ & $18(60)$ \\
\hline
\end{tabular}

\section{Figures}

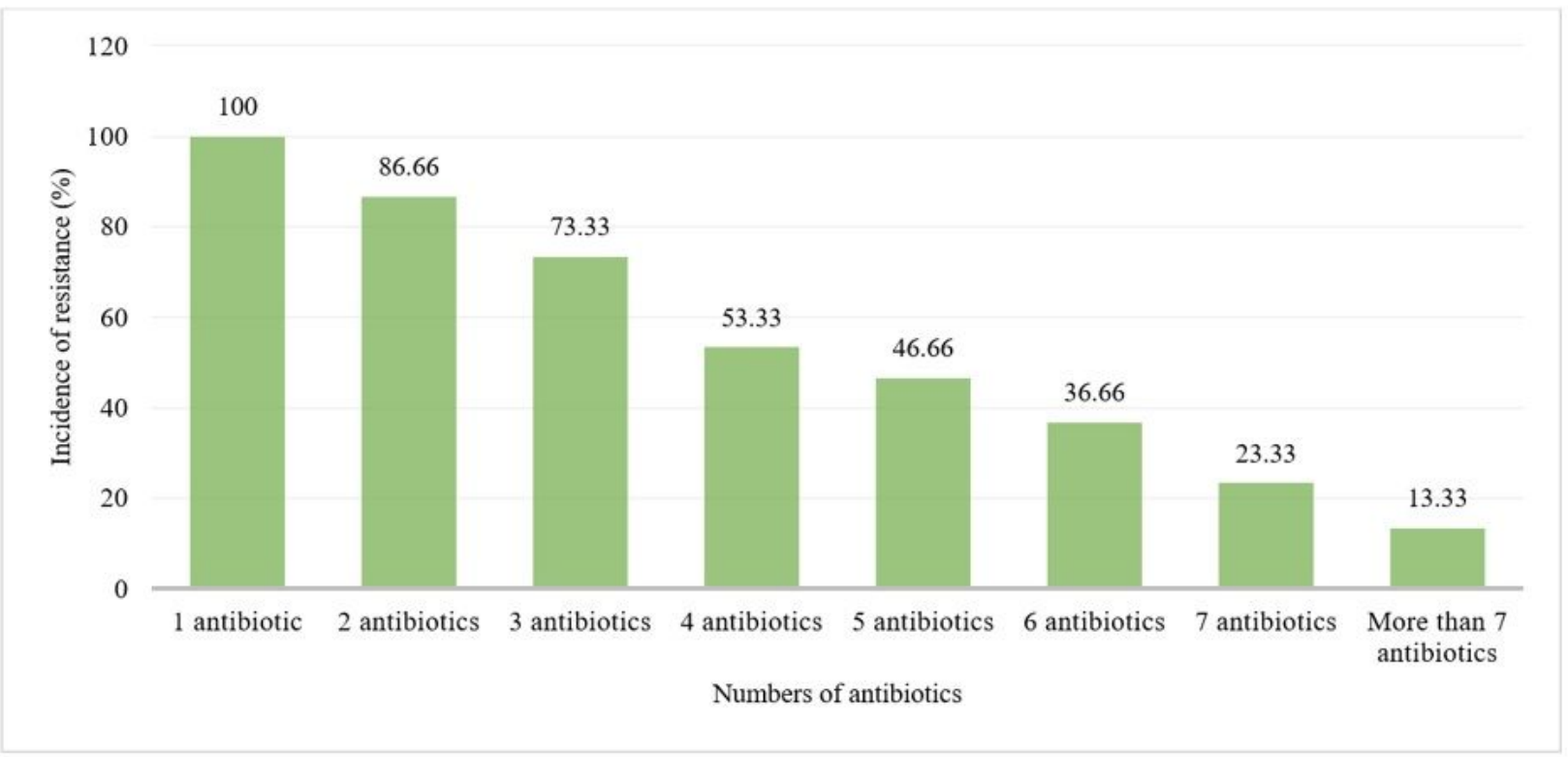

Figure 1 
Prevalence of multidrug resistant-S. aureus bacteria isolated from examined powdered packaged medicinal plants and bottle herbal distillate samples. Frequencies were measured according to a total number of $30 \mathrm{~S}$. aureus isolates.

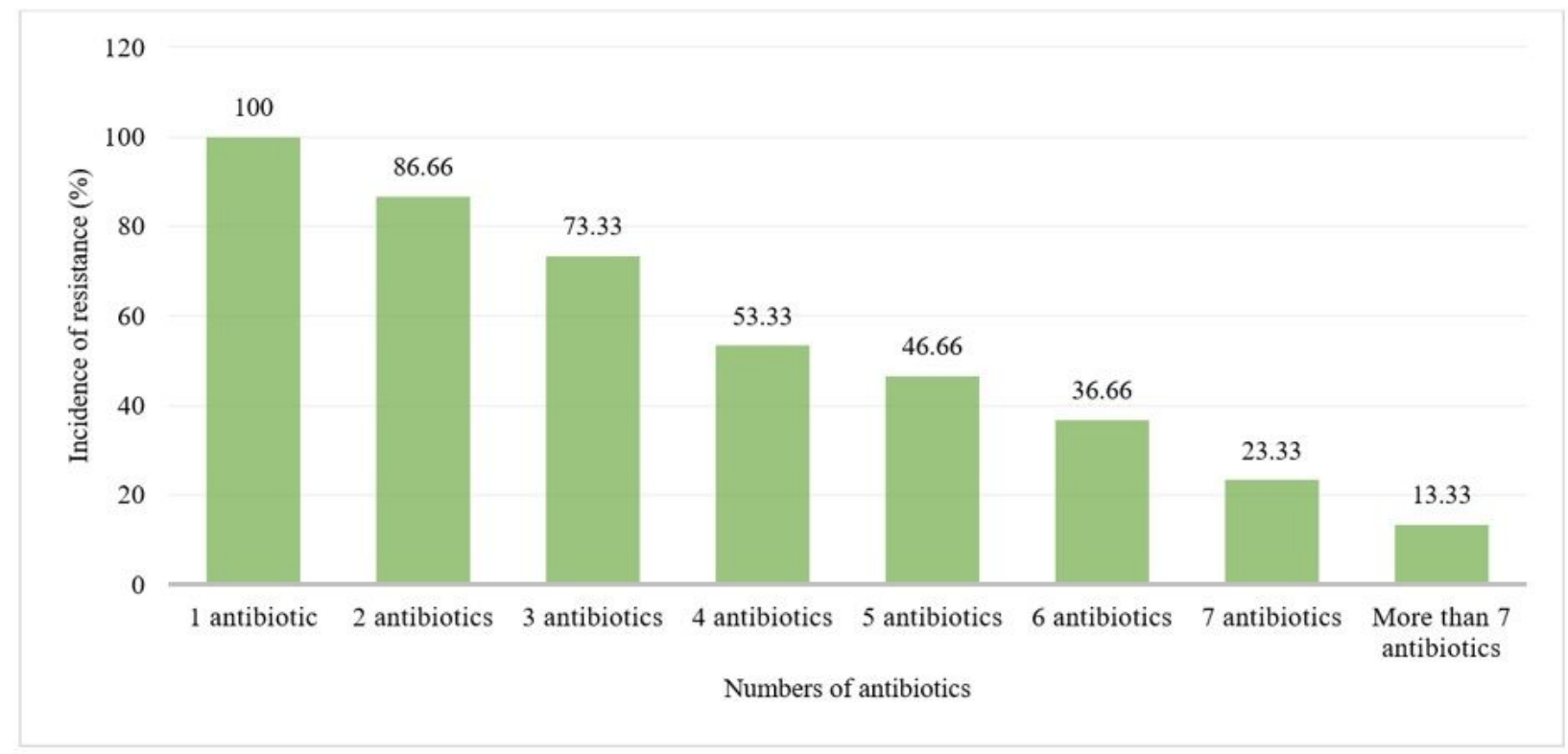

\section{Figure 1}

Prevalence of multidrug resistant-S. aureus bacteria isolated from examined powdered packaged medicinal plants and bottle herbal distillate samples. Frequencies were measured according to a total number of $30 \mathrm{~S}$. aureus isolates. 